\title{
Research on College English Teaching Supported by Information Technology
}

\author{
Taohua Xiao \\ English Teaching and Research Office \\ Jiangxi Institute of Fashion Technology \\ Nanchang, China 330201
}

\author{
Lina $\mathrm{Wu}$ \\ English Teaching and Research Office \\ Jiangxi Institute of Fashion Technology \\ Nanchang, China 330201
}

\begin{abstract}
Under the background of higher education reform, in order to promote course construction and improve teaching efficiency of college English, teaching through advanced information technology and teaching idea avails the improvement of teachers' specialty literacy and the training of students' ability in independent study and lifelong learning and guides the reform of college English teaching.
\end{abstract}

Keywords-information technology; college English; reform; lifelong learning

\section{INTRODUCTION}

\section{A. Connotation of Information Technology}

Information technology refers to hardware infrastructure, software and service that manage and transfer information. It centers on computer technology, micro electronic technique and communication technology and combines with integrated circuit technique, $\mathrm{CD}$ technology and robot technology. These technologies or technology integration obtain, store, process, display, transmit or apply numerous information of different formats with distributed storage. ${ }^{1}$ The informatization in educational field means roundly and deeply applying modern information technology to promote educational reform and development and finally will form brand new educational form, educational informatization.

\section{B. College English Teaching}

At present, the highlight of teaching reform of college English is the "supportive" position of computer network in college English course. Front line English teachers practice new teaching model, make the most of modern information technology and depend on rich network English resources, update teaching contents at the same time value classroom teaching. The development tendency is the integration of excellent teachers and advanced network technology. Correctly dealing with relation of the two, integrating information technology with foreign language course and establishing network ecological environment suitable for foreign language teaching avails and achieves tangible results in improving course teaching, promoting the reform of teaching contents and methods and arousing students' learning interests and improving teaching effects and quality. ${ }^{2}$

\section{PRinCIPLes That INFormation-BASED TEAChING SHOULD FOLLOW}

The informatization of college English teaching must follow basic principles of information-based teaching ${ }^{3}$, including:

\section{A. Technology}

1) Digitalization: The information technology used in college English teaching mainly refers to the computer-based digital technology which make the equipment simpler, performance more reliable and standard more uniform in English teaching.

2) Network: Advantages of network such as resource sharing, unlimited time and space and multiple interaction and convenience of cooperation can be applied to web-based learning and teaching of college English.

3) Multimedia: Application of multimedia to English course changes the situation that the teacher writes key points on the blackboard and students take note blindly. Students who write slowly are absorbed in writing and fail to listen. The computer-based multimedia technology with images and texts can attract students' attention. Moreover, it virtualizes things in reality and stimulates students' imagination.

4) Intelligence: The core technology of information-based education is artificial intelligence that humanizes English teaching and simplifies complicated things.

\section{B. Education}

1) Multimedia teaching materials: Application of multimedia teaching to college English uses hypermedia technology to connect things related and make the teaching contents structured and present it in front of learners. More vivid things are accepted by learners more easily.

2) Resource globalization: English educational resources on the internet are very rich and cover listening, speaking, reading and writing. For example, the learning website of Wangwang English almost includes learning at all stages and levels. Network resources are provided for English fans and learners to visit and learn whenever and wherever possible.

3) Individuality of teaching: English teachers carry out individualized teaching or provide proper help and guidance 
according to students' personality, mentor system in AI system as well as students' personalized requirements and characteristics.

4) Independent learning: In college English teaching supported by information technology, electronic learning materials and resources on multimedia and network make students' independent learning convenient. Independent learning with technical support also becomes inevitable.

\section{APPLICATION OF INFORMATION TECHNOLOGY TO COLLEGE ENGLISH TEACHING}

\section{A. Establishment of Information-Based Teaching Idea}

Application of information technology to college English teaching requires teachers to alter teaching methods and means especially teaching idea. They must transfer from "soloist" to "accompanist", not to impart knowledge but to help students in development, organization and management of their knowledge, continuously guide them instead of shaping them. Teaching is no longer knowledge-based and discipline-based but student-oriented to organically integrate knowledge, ability and attitudes. ${ }^{4}$ The quality of college English teaching depends on students' initiative. Therefore, the knowledge imparting of teachers is transformed into students' active learning. Students play the dominant role in class so that they have stronger learning initiative and self-confidence and will be interested in class and learning. It will lay a solid foundation for learners' lifelong learning.

\section{B. Construction of Information-Based Teaching Environment}

First, schools should establish language laboratory required by English teaching and open LAN and WAN, which are the most hardware equipment required by college English teaching. It needs funds, so experts can be invited to evaluate and investigate and survey, in order to most reasonably distribute and optimize the funds.

Second, develop software and network courses, which are soft power for the application of information technology to college English teaching. It is very difficult for a school to finish and the investment is tremendous. It will be more scientific, reasonable and effective with national support. Schools only need to purchase related network textbooks, courses or evaluation or management software.

\section{Establishment of Information-Based Teaching Management Team}

Establishment of scientific and reasonable teaching management team is a key part to apply information technology to college English teaching. First, choose proper members including teachers, administrators and technicians. Old, middle-aged and young teachers, senior, medium-grade and junior professional titles are included. Second, the division of labor, the functions of teachers, administrators and technicians must be clear to guarantee smooth and ordered teaching. Finally, scientific and reasonable system of rewards and penalties must be formulated.

\section{Carry out Information-Based Teaching of English}

Application of information technology in college English teaching changes teachers' teaching model and students' learning style and finally improves students' comprehensive quality and ability of lifelong learning. Specifically, the following aspects should be considered. First, the informationbased software and hardware environment in schools should be considered in course provision. Second, in English teaching, information technology must purposefully relate to contents of classroom teaching and learners' initiative to optimize the effects of information-based learning. Scientific and reasonable information-based learning environment of college English should give full play to learners' personality. Students choose learning styles and contents according to their ability and preference to optimize learning effects. Finally, in teaching management, comprehensive teaching management software can be developed and utilized to manage documents of teaching management and monitor teaching process, carry out online training of teachers and online interactions between teachers and students. 5

\section{CONCLUSION}

Application of information technology to college English teaching lets learners break the limitation of time and space so that they can learn and discuss college English whenever and wherever possible. It will inevitably promote and change English learners' cognitive style as well as avail putting lifelong teaching, learning-based society and lifelong learning into practice. Therefore, college English teaching supported by information technology improves course construction, teachers' teaching ability and level and students' English learning effects also lays solid foundation for students' lifelong learning.

\section{REFERENCES}

[1] Zhang Jianwei, Sun Yanqing. Constructive Learning: Exploration on Learning Scientific Integration [M], Shanghai: Shanghai Educational Publishing House, 2005

[2] Wang Shouren. Investigation on Current Situation, Reform and Development Direction of College English Teaching in Our Country [J], Foreign Languages in China, 2011(9)

[3] Zhu Zhiting, Zhong Zhixian. Modern Educational Technology: Promote Multiple Intellectual Development [M], Shanghai: East Normal University Press, 2003

[4] Zhong Zhixian. Informative Teaching Model: Theory Construction and Practical Examples [M], Beijing: Educational Science Press, 2005

[5] Zhao Guiying. Application of Information Technology in College English Teaching [J], Information Science, 2012(06) 